\title{
Religious Education Values in Gita Savitri Devi's Rentang Kisah and Andori Andriani's Doriyaki Novels
}

\author{
Oktaviana Araminta Putriyanti ${ }^{1}$, Retno Winarni ${ }^{2}$, Muhammad Rohmadi ${ }^{3}$ \\ 1,2,3 Postgraduate Education Indonesian Language FKIP Sebelas Maret University, Indonesia \\ oktavianaputri@student.uns.ac.id
}

\begin{abstract}
Religious education is one pillar in human life. This article aims to determine the values of religious education contained in literary works, one of which is a novel. Novels are literary works that attract the readers' attentions the most because of the plot. Many modern novels containing the values of religious education can be imitated. The RentangKisah by Gita Savitri Devi and Doriyaki by AndoriAndriani are modern novels which contain the values of religious education. These can be seen in the life stories of both. Different family life and social environment make these two novels have different religious education values in their stories. This study is a qualitative descriptive study. The data were collected by taking a note the excerpts of Gita and Dori which contain religious education values. This study aims to determine the values of religious education in the RentangKisah and Doriyaki novels. The results of this study are the values of religious education shown by Gita and Dori.
\end{abstract} Keywords: Religious education value; novel.

\section{Introduction}

A novel is a literary work created from the author's imagination. It is the picture of life because the plot contained in the novel was born through the life experience of either the author himself or others that serves as the idea. According to Wellek and Warren (1982: 282), a novel is a picture of life and real behaviors from the time when the novel was written. It depicts the journey of life that the character experiences. According to Tarigan, (2011: 60), a novel is an imaginative work that tells the whole side of the systematics of a person's life or several characters' lives.

A novel is created not only to entertain but also to transfer messages in people's lives. This is as Foster says that a novel is one of an extended fictional prose narrative. It differs from allegory (which functions to teach some sort of moral lesson) and romance (with its emphasis on spectacular and exciting events designed to entertain) in its emphasis on character development. According to Jassin (1985: 78), a novel tells the life of someone who was born from a conflict, a dispute that changes the fate of the character. This is in line with the opinion of Mursal Esten (1990: 12) that the novel is a literary work that uses the conflicts of human life that ultimately make a change in the way of life of the character

Religious education values are the internalization of human attitudes to obey God. According to Nurgiyantoro (2005: 326), religious education values are high spiritual values and absolutely come from human belief in God. Religious values are the center of all norms in social life. The values come from the belief of everyone. According to Semi (1993: 21), religion is the key to history. If we want to understand the soul of a society, we must understand its religion first. Religious values are the values that refer to human freedom to choose their faith related to what they believe.

Religious values contained in literary works are something that can be taken to be used as a way of life because many works contain religious education values, especially novels. The existence of religious education values in a literary work can be a special attraction for its readers. 
The Rentang Kisah novel by Gita Savitri Devi and Doriyaki by Andori Andriani are modern novels of the best-seller category as they bring stories based on personal experiences about adolescent life problems of finding identity. The stories are added with various family and social conflicts. Living in other countries with a minority of Muslims makes Gita and Dori try to adjust themselves. Many habits and norms in Islam must be obeyed even though many people around them have different beliefs. There are a lot of studies on the values of religious education in novels, but there are still few researchers who examine the value of education in a novel where the characters live in a country where Muslims belong to a minority.

The relevant study to this study is the one conducted by Nindy Elrini, Harris Effendi and Abdurahman with the title "Educational Values in Mamak Novel by Nelson Alwi." It was published in the Puitika journal Vol. 14, No. 1, April 2018. The study shows the existence of educational values in Mamak novel by Nelson Alwi which include religious, toughness, and caring education values. However, of the three values contained in the Mamak novel, the highest educational value is the caring education value.

Another relevant study on educational values in the novel was conducted by Devi Yenharizal, Nurizzati, and Elly Ratna. The study was entitled "Educational Values in the Eliana Novel by Tere Liye." It was published in the journal of Pendidikan Bahasa dan Sastra Indonesia, Vol. 1, No. 1, September 2012. It was found that (1) 19 behaviors of an actor contain character education, such as honesty, patience, simplicity, bravery, sincerity, and being grateful; (2) 8 behaviors of an actor contain educational intelligence, such as logical and creative thinking; (3) 7 behaviors of an actor contain social education, such as being friendly, helping one another, respecting and appreciating; and (4) 16 behaviors of an actor contain family welfare education, such as raising children and implementing households. The third relevant study conducted by Gunawan Andry, Mustifa Ali, and Riadi Bambang, entitled "Religious Values in Habiburrahman El Shirazy's Ayat-Ayat Cinta 2 Novel and Its Design". The study was published in the Kata journal in March 2018. It was found that Ayat-Ayat Cinta 2 novel by Habiburrahman El Shirazy contains religious values which include faith, sharia, and morals.

The next relevant study was conducted by Fitriati Siti entitled "Educational Values of Sang Pemimpi Novel by Andrea Hirata." It was published in the Pesona journal Vol. 1, No. 2, January 2015. The results of this study imply that Sang Pemimpi novel by Andrea Hirata has educational values including moral values such as helping, courage and commitment, cooperation, caring and empathy, humor, responsibility, beauty, religion and truth. Another relevant study was conducted by Hassan Ummu Hani Abu, entitled "The Representation of Islamic Teaching in the Novels by Habiburrahman El Shirazy." It was published in the Pengajian Media Malaysia journal, Vol. 15, No. 1, 2013. The result of the study is that AAC and KCB novels contain high educational values and Islamic concepts which are implemented on the Islamic beliefs, law (the acts of devotion and muamalah), and morals.

\section{II.Research Method}

This study is a qualitative descriptive study with the data in the form of paragraphs contained in the Rentang Kisah novel by Gita Savitri Devi and Doriyaki by Andori Andriani. The method used was the library method by collecting the data by reading relevant books and articles to this study. The data sources used were Gita Savitri Devi's Rentang Kisah and Andori Andriani's Doriyaki as well as books that refer to the study. The sampling technique 
used was purposive sampling. The data were collected using 2 techniques, namely reading and note-taking techniques. The data and theory triangulations were used. The data were analyzed by giving interpretation and describing the findings part by part. Next, a general conclusion about the data description was formulated and then the complete results were presented in a written form.

\section{Results and Discussion}

There are several characters, both the main and innate characters in story of a novel. Each of them must have his/her distinctive character. A character in a story plays the plot in the story. The events in a novel contain various messages or values. One of the educational values in the novel is the religious education value. This value can be found through the characters' behaviors in the story. The religious education values contained in a novel have some similarities and differences. The classification of religious education values in Gita Savitri Devi' Rentang Kisah and Andori Andriani's Doriyaki is as follows.

\subsection{Religious Education Values in Gita Savitri Devi's Rentang Kisah Novel}

The religious education value is a binding value between humans and God. Religion is a human belief in the existence of God. Religious values are the way of life that will make harmony in human life according to guidance and order based on their beliefs. One's belief cannot be forced, neither can Paul's. Gita did not want to make Paul follow her belief. It is seen in the following excerpt.

Aku membaca bab 24, "Perpecahan Keluarga". Bab ini menceritakan bagaimana sedihnya Rasulullah atas ketidakinginan beberapa kerabatnya untuk menerima dakwah beliau dan menerima Islam sebagai agamanya. Maka, Allah Awt, menurunkan wahyu untuk membantu meringankan beban tanggung jawab beliau dalam menyebarkan Islam. Ayat yang membuatku sadar akan satu hal dan nggak pernah aku lupa.

Sesungguhnya engkau tidak dapat memberi petunjuk orang yang engkau cintai, melainkan Allahlah yang memberi petunjuk kepada siapa saja yang dikehendaki-Nya. (Q.S al-Qasas [28]:56).

Secara nggak sadar aku hanya menatap halaman tersebut. Pikiranku melayang ke manamana, kemudian dipenuhi oleh rasa penyesalan dan aku merasa tiba-tiba semuanya menjadi jelas (Devi, 2017:95).

The above excerpt clearly illustrates that Gita feels very close to the Creator. At first, Gita did want Paul to convert, following her to embrace Islam. However, as time went by, she realized that no one could turn the heart upside down but God.

Finally, she decided to wear a veil after considering a lot of things that would happen. Wearing a veil is an obligation for Muslims. Gita really thought of this decision deeply. It is seen in the following excerpt.

Aku cukup malu dengan siriku sendiri. Buatku kerudung itu bukan hanya sekedar kain, tapi simbol agama. Hubungannya langsung ke Tuhan. Entah apa yang kupikirkan pada saat itu samapai aku bisa terlihat seperti mengganggap remeh. Berlama-lama menyesali perbuatan nggak akan mengubah apa-apa, pikirku. Aku pun memutuskan untuk pakai kerudung. Dan semoga kali ini untuk selama-lamanya (Devi, 2017:125). 
Based on the above excerpt, it shows that Gita already has a strong intention to wear a veil, not solely to look like a Muslim. However, she tried to carry out the obligations of a Muslim. She hopes that this decision will really make her more istiqomah (steadfast).

She felt comfortable after wearing a veil. She felt safe because she had covered her body. Gita feels that she is always protected by God through her veil. It is seen in the following excerpt.

Malah sekarang aku merasa lebih aman. Walau kerudung ini hanya selembar kain, kain ini berhasil bikin hati aku tenang. Ke mana pun aku pergi, aku merasa seperti ada yang menjaga. Merasa selalu aman karena lebih dekat dengan Allah (Devi, 2017:130).

Based on the above excerpt, it shows that Gita is more comfortable with her life. Gita finds comfort and always feels close to God. She feels that learning more about her religion brings a big change for her.

\subsection{Religious Education Values in Andori Andriani's Doriyaki Novel}

Whatever happens in her life, Dori must be grateful. Behind her illness, she found back the lost pieces of harmony in her family. It is seen in the following excerpt.

Namun, di satu sisi, gue bersyukur bisa dirawat di rumah sakit karena itu satu-satunya tempat gue bisa merasa tnang meski sejenak. Kalo gue sakit, nyokap khawatir, bikap setia menemani sepanjang malam. Kami seperti kembali menjadi sebuah keluarga (Andriani, 2015:40).

Based on the excerpt above, Dori is grateful for the illness God gave her. It is undesirable, but Dori can get together with her parents due to the illness. Behind the events that occurred, there must be wisdom that is far better.

Be grateful for the blessing God gave. Not everyone has the opportunity and life like Dori. As humans, we must be grateful in life. It is seen in the following excerpt.

Selama ini gue selalu melihat ke atas, kehidupan orang lain kelihatan lebih indah daripada kehiudpan sendiri. Gue iri, merasa ngak adil. Padahal, di luar sana masih banyak yang lebih susah hidupnya.malah mungkin, masalah gue nggak ada apaapanyasama sekali dibanding mereka. Ya, gue harus bangkit, nggak boelh terus tenggelam dalam kesedihan. Harus bisa mensyukuri apa yang gue miliki sekarang.

Dulu gue mikir Tuhan itu jahat, kasih ujian seberat ini kepada gue dan keluarga. Tapi, akhirya gue sadar. Tuhan nggak akan memberi ujian melebihi kemampuan hambanya. Berarti, Tuhan tahu gue mampu dan uat melewati ini semua. Berarti gue harusyakin sama diri sendiri, nggak boleh putus ada dan nyerah gitu aja (Andriani, 2015:44).

Based on the excerpt above, Dori must be grateful for whatever she already has in her life. We must stay away from being jealous of other people's lives. Envy only makes someone not grateful for his life.

God will prepare something more beautiful for Dori. She must sincerely accept her mother's passing away. After all, sincerity will open a bright path for her mother to heaven. It is seen in the following excerpt.

"Inilah jalan terbaik yang Tuhan beri untuk keluarga gue," hibur gue dalam hati. Setiap rasa sdih datang, gue sebagai anak hanya bisa mendoakan yang 
Based on the above excerpt, Dori is sincere with everything happened in her life. She can only pray for her mother. She does not want to be always sad sadness because after all she must continue her life.

\section{Conclusion}

Based on the data analysis carried out, there exist religious education values in the Rentang Kisah novel by Gita Savitri Devi and Doriyaki novel by Andori Andriani. The values are related to the vertical relationship between humans and God. The religious value that can be drawn from Gita Savitri Devi's Rentang Kisah is to pray to God. Praying is a way for someone to ask God for something because whatever happens in our lives is all God's will. Understanding religion does not only mean praying five times a day and fasting. Every human being who has a religion must deepen the teachings of his religion because religion is an important foundation in life.

Learning and understanding Islam can be done by following routine religious studies at the mosque and discussing with other religious people. One of the obligations of a Muslim is to cover her body with a veil. With a veil, a Muslim can perfect half of her religion to be a devout Muslim.

The religious education value contained in Andori Andriani's Doriyaki novel is to be grateful. No matter whatever happens in life, whether it is good or bad, we must accept it and be grateful for. Be grateful for the blessing Allah has given to each of His servants. Not everyone has the opportunity and life like others. We must stay away from being jealous of other people's lives. Envy only makes someone not grateful for his life.

There must be a way out of every test given by God. God will not give a test beyond the limits of His servant's ability. Praying is the only way for every servant when he wants something. We must let go of everything that happens in life and must not always be sad because after all we must continue our lives.

\section{Acknowledgement}

My gratitude is to convey to the parties who have been involved in this research, such as the Supervisor and editorial team of BIRLE Journal. Hope and the prayer of researchers, hopefully this article contributes in the field of education, especially the field of literature study around the world.

\section{Reference}

Andriani, Andori. (2015). Doriyaki: Jauh Di Mata Dori Di Hati. Jakarta: Bukune.

Devi Savitri Devi. (2017). Rentang Kisah. Jakarta: Gagas Media.

Devi Yenharizal, Nurizzati, and Elly Ratna. (2012). "Nilai-nilai Pendidikan dalam Novel Eliana Karya Tere Liye". Jurnal Pendidikan Bahasa dan Sastra Indonesia, Vol. 1, No. 1, September 2012.

Fitriati Siti. (2015). "Nilai-Nilai Pendidikan Novel Sang Pemimpi Karya Andrea Hirata". Jurnal Pesona.

Forster, E. M. (1927). Aspects of the Novel. New York: Harcourt, Brace \& Company.

Gunawan Andry, Mustifa Ali, dan Riadi Bambang. (2018)."Nilai-nilai Religius dalam Novel Ayat-Ayat Cinta 2 Habiburrahman El Shirazy dan Rancangannya". Jurnal Kata.

Hassan Ummu Hani Abu. (2013). "The Representation of Uslamic Teaching in The Novels By Habiburrahman El Shirazy". Jurnal Pengajian Media Malaysia. 
Jassin, H.B. (1985). Tifa Penyair dan Daerahnya. Jakarta: PT. Gunung Agung.

Mursal Esten. (1989). Kesusastraan: Pengantar Teori dan Sejarah. Bandung: Angkasa.

Nindy Elrini, Harris Effendi, and Abdurahman. (2018). "Nilai-nilai Pendidikan dalam Novel Mamak Karya Nelson Alwi". Jurnal Puitika Vol. 14, No. 1, April 2018.

Nurgiyantoro. (2005). Sastra Anak, Pengantar Pemahaman Dunia Anak. Yogyakarta: Gadjah Mada University Press.

Semi, Atar. (1993). Anatomi Sastra. Bandung: Angkasa Raya.

Tarigan, Henry Guntur. (2011). Dasar-Dasar Psikosastra. Bandung: Angkasa Group.

Wellek, Rene dan Austin Warren. (1962). Theory of Literature. New York: A Harvest Broks. 